\title{
Hubungan Iklim Organisasi dengan Kinerja Pegawai di Bagian Sekretariat Dinas Pendidikan Provinsi Sumatera Barat
}

\author{
Rindu Aria Friska ${ }^{1}$, Hadiyanto ${ }^{2}$, Nurhizrah ${ }^{3}$, Hanif Al Kadri ${ }^{4}$ \\ $1,2,3,4$ Administrasi Pendidikan, Universitas Negeri Padang \\ Rindu Aria Friska1, e-mail: ariafriska12@gmail.com \\ Hadiyanto ${ }^{2}$, e-mail: hadiyanto@ fip.unp.ac.id \\ Nurhizrah Gistituati ${ }^{3}$, e-mail: gistituatinurhizrah@gmail.com \\ Hanif Al Kadri , e-mail: hanifalkadri@fip.unp.ac.id
}

\begin{abstract}
This study examines as well as aims to extract information about the relationship between organizational climate and employee performance at the Secretariat of the Education Office of West Sumatra Province. The method used in this research is correlation research and quantitative methods. All employees of the Secretariat of the Education Office of West Sumatra Province became the population in this study as many as 79 respondents and the sample was 44 respondents. The research instrument used a Likert scale model questionnaire. Analysis of research data using the Product Moment correlation formula in SPSS (Statistical Package and Science). The results of data acquisition for variable $\mathrm{X}$ with a mean of 116.57 and a score of $82.07 \%$ in the conducive category, each indicator obtained 26.20 completeness of sarpras, 30.36 trust, 31.02 leadership support and 23.14 employee involvement. While the results of the acquisition of variable $\mathrm{Y}$ with a mean of 110.80 and a score of $86.53 \%$ in the high category, each indicator $=44.64$ quality, 33.09 quantity and 38.84 cooperation. Correlation data using SPSS for both variables shows the number 0.001 with a $95 \%$ confidence level, if the number shows $<0.05$ then the variables $\mathrm{X}$ and $\mathrm{Y}$ are said to be correlated. So it can be concluded that the hypothesis which reads "there is a relationship between organizational climate and employee performance in the Secretariat Section of the West Sumatra Provincial Education Office" can be accepted.
\end{abstract}

\begin{abstract}
Abstrak
Penelitian ini mengkaji sekaligus bertujuan menggali informasi mengenai hubungan iklim organisasi terhadap kinerja pegawai di Bagian Sekretariat Dinas Pendidikan Provinsi Sumatera Barat. Metode yang digunakan dalam penelitian ini dengan menggunakan jenis penelitian korelasi serta menggunakan metode kuantitatif. Semua pegawai Bagian Sekretariat Dinas Pendidikan Provinsi Sumatera Barat menjadi populasi dalam penelitian ini sebanyak 79 responden dan sampelnya sebanyak 44 responden. Intrumen penelitian menggunakan Angket model Skala Likert. Analisa data hasil penelitian memakai rumus korelasi Product Moment di SPSS (Statistikal Package and Science). Hasil perolehan data variabel X dengan Mean 116,57 dan skor yang diperoleh 82,07\% dengan kategori kondusif, masing-masing indikator memperoleh 26,20 kelengkapan sarpras, 30,36 kepercayaan, 31,02 dukungan pimpinan dan 23,14 keterlibatan pegawai. Sedangkan hasil perolehan variable Y dengan Mean 110,80 dan skor yang diperoleh 86,53\% dengan kategori tinggi, masing=masing indikator memperoleh 44,64 kualitas, 33,09 kuantitas dan 38,84 kerjasama. Data korelasi dengan menggunakan SPSS kedua variabel menunjukkan angka 0,001 dengan taraf kepercayaan 95\%, apabila angka menunjukkan $<0,05$ maka variabel $\mathrm{X}$ dan $\mathrm{Y}$ disebut berkorelasi. Jadi dapat ditarik kesimpulan bahwa hipotesis yang berbunyi "adanya hubungan antara iklim organisasi dengan kinerja pegawai di Bagian Sekretariat Dinas Pendidikan Provinsi Sumatera Barat" dapat diterima.
\end{abstract}

Kata Kunci: Iklim Organisasi, Kinerja Pegawai

How to Cite: Rindu Aria Friska ${ }^{1}$, Hadiyanto ${ }^{2}$, Nurhizrah ${ }^{3}$, Hanif Al Kadri ${ }^{4}$. 2021. Hubungan Iklim Organisasi dengan KInerja Pegawai di Bagian Sekretariat Dinas Pendidikan Provinsi Sumatera Barat. Journal Education Administration and Leadership, Vol (N): pp. XX-XX, DOI: 10.24036/XXXXXXXXXX-X-XX 

use, distrution, and reproduction in any medium, provided the original work is properly cited. (C2020 by author.

\section{Pendahuluan}

Organisasi merupakan wadah atau tempat sekumpulan orang yang memiliki tujuan yang sama dan diikat oleh sebuah aturan. Menurut Gibson "Organisasi bisa melakukan kinerja dengan efisien dan efektif jika tetap dalam kaidah karakteristiknya, yaitu mempertimbangkan struktur, status hirarki, peran dan norma yang ada". Kinerja dipenagruhi oleh beberapa faktor, antara lain iklim organisasi, etos kerja dan disiplin kerja (Mutaqin 2010).

Lingkungan organisasi dapat dipengaruhi dengan adanya iklim organisasi. Baik atau buruknya suatu iklim organisasi ditentukan oleh anggota yang ada di dalam organisasi itu. Dalam Hadiyanto (2016: 3), Netwell (1978) menatakan bahwa iklim organisasi berkaitan dengan semua keadaan emosianal dari sekelompok orang yang mencakup perasaan dan reaksi kepada keseluruhan system.

Dinas Pendidikan Provinsi Sumatera Barat (Disdik-Sumbar) merupakan salah satu bentuk organisasi yang memiliki iklim organisasi di dalamnya. Berdasarkan pengamatan penulis selama melaksanakan kegiatan Praktek Lapangan Manajemen dari Desember 2019 - Februari 2020 dapat diketahui iklim organisasi dan kinerja pegawai di Dinas Pendidikan Provinsi Sumatera Barat masih kurang. Beberapa fenomena yang ada:

1. Sebagian pegawai kurang menyadari dengan pekerjaannya

2. Masih kurangnya koordinasi dan perencanaan pada tim kerja dalam melaksanakan pekerjaannya. Seperti halnya pegawai diberikan tanggungjawab yang besar, tetapi pegawai tidak memiliki wewenang untuk mengambil keputusan pada pekerjaan sedangkan pimpinan sering tidak berada di ruangan.

3. Rendahnya empati yang terjadi sesama antar pegawai, seperti kurangnya kebersamaan dan kurang terciptanya suasana saling mempercayai, sehingga membuat beberapa pegawai memilih tertutup terhadap kesulitan yang dialami.

4. Masih kurangnya penghargaan bagi pegawai yang berprestasi. Terlihat dari pegawai yang kurang semangat menyelesaikan pekerjaannya tepat waktu, karena beranggapan hasil kerja tidak dihargai oleh piminan jika menyelesaiakan pekerjaan tepat waktu.

5. Sebagian pegawai kurang partisipasi untuk kegiatan yang diadakan oleh dinas. Dapat dilihat dari beberapa pegawai yang jarang mengikuti kegiatan rutin senam pagi setiap hari rabu dan memilih untuk duduk di dalam ruangan, sehingga kegiatan tersebut hanya diramaikan oleh mahasiswa dan siswa magang.

Berdasarkan fenomena tersebut, maka penulis bertujuan ingin mengkaji lebih mendalam mengenai iklim oerganisasi, kinerja pegawai dan adakah hubungan antara iklim organisasi dengan kinerja pegawai di Bagian Sekretariat Dinas Pendidikan Provinsi Sumatera Barat. Hal yang akan dikaji dalam iklim organisasi yaitu kelengkapan sarpras, kepercayaan, dukungan pimpinan dan keterlibatan pegawai. Sedangkan hal yang akan dikaji dalam kinerja pegawai yaitu kualitas, kuantitas dan kerjasama.

\section{Metode Penelitian}

Penelitian yang dilakukan berjenis penelitian korelasi yang menggunakan metode penelitian kuantitaif.. Populasi pada penelitian ini berjumlah 79 orang yang merupakan seluruh pegawai Bagian Sekretariat DisdikSumbar ada 3 Sub Bagian pertama Umum 25 orang, kedua Kepegawaian 23 orang dan ketiga Keuangan 31 orang. Penarikan sampel dilakukan dengan memakai Rumus Slovin bertaraf signifikansi 10\%. Sampel berjumlah 44 responden, terdiri atas 14 oranng di Sub Bagian Umum, 13 orang di Sub Bagia Kepegawaian dan 17 orang di Sub Bagian Keuangnan.

Intrumen penelitian dengan menggunakan Angket berskala Likert yang bertujuan untuk mengikuti tingkah laku dan opini individu atau sekelompok terhadap kejadian sosial, jawban terdiri dari jawaban yang positif sampai dengan jawaban negative (Sugiyono, 2009: 134)

Uji validditas dan reliabilitas pada angket ini menggunakan SPSS (Statistikal Package and Science) dengan taraf kepercayaan 95\%. Variabel X valid 27 item, sedangkan variabel Y valid 27 item. Kedua variabel $\mathrm{X}$ dan $\mathrm{Y}$ menunjukkan hasil reliabel.

Analisa data hasil penelitian memakai rumus korelasi Product Moment di SPSS (Statistikal Package and Science).

\section{Hasil Pembahasan}

\subsection{Hasil}

a. Deskripsi Data Kinerja Pegawai (Variabel Y)

Tabel 1. Rata-rata Perindikator Kinerja Pegawai 
Rindu Aria Friska ${ }^{1}$, Hadiyanto $^{2}$, Nurhizrah $^{3}$, Hanif Al Kadri ${ }^{4}$ Hubungan Iklim Organisasi dengan Kinerja Pegawai di Bagian Sekretariat Dinas Pendidikan Provinsi Sumatera

Barat

\begin{tabular}{|c|l|c|}
\hline No & \multicolumn{1}{|c|}{ Indikator } & Rata-rata \\
\hline 1. & Kualitas & $\mathbf{4 4 , 6 4}$ \\
\hline 2. & Kuantitas & $\mathbf{3 3 , 0 9}$ \\
\hline 3. & Kerjasama & $\mathbf{3 8 , 8 4}$ \\
\hline \multicolumn{2}{|c|}{ Skor rata-rata } & $\mathbf{3 8 , 8 6}$ \\
\hline
\end{tabular}

Tabel 1 di atas memperlihatkan skor rata-rata paling tinggi terdapat dikerjasama sejumlah 38,84 , sedangkan skor rata-rata paling rendah terdapat dikuantitas sejumlah 33,09. Secara umum skor rata-rata kinerja pegawai Bagian Sekretariat Dinas Pendidikan Provinsi Sumatera Barat adalah 38,86. Artinya secara umum kinerja pegawai Bagian Sekretariat Dinas Pendidikan Provinsi Sumatera Barat sudah tinggi.

b. Deskripsi Data Iklim Organisasi

Tabel 2. Rata-rata Perindikator Iklim Organisasi

\begin{tabular}{|c|l|c|}
\hline No. & \multicolumn{1}{|c|}{ Indicator } & Rata-rata \\
\hline 1. & Kelengkapan sarana dan prasarana & $\mathbf{2 6 , 2 0}$ \\
\hline 2. & Kepercayaan & $\mathbf{3 0 , 3 6}$ \\
\hline 3. & Dukungan pimpinan & $\mathbf{3 1 , 0 2}$ \\
\hline 4. & Keterlibatan pegawai & $\mathbf{2 3 , 1 4}$ \\
\hline \multicolumn{2}{|c|}{ Skor rata-rata } & $\mathbf{2 7 , 6 8}$ \\
\hline
\end{tabular}

Tabel 2 menujukkan skor rata-rata paling tinggi terdapat didukungan pimpinan sejumlah 31,02 , sedangkan skor rata-rata paling rendah etrdapat diketerlibatan pegawai sejumlah 23,14 . Secara umum skor rata-rata iklim organisasi Bagian Sekretariat Dinas Pendidikan Provinsi Sumatera Barat adalah 27,68. Artinya secara umum kinerja pegawai Bagian Sekretariat Dinas Pendidikan Provinsi Sumatera Barat sudah baik.

c. Hubungan Antara Iklim Organisasi Dengan Kinerja Pegawai

Tabel 3. Tafsiran Rata-rata Variabel Penelitian

\begin{tabular}{|l|l|c|c|c|c|}
\hline No & \multicolumn{1}{|c|}{ Variabel } & Rata-rata & $\begin{array}{c}\text { Skor } \\
\text { Ideal }\end{array}$ & Skor didapat & Kategori \\
\hline 1. & Iklim Sekolah & 116,57 & 135 & $82,07 \%$ & Kondusif \\
\hline 2. & Kinerja Pegawai & 110,80 & 135 & $86,53 \%$ & Tinggi \\
\hline
\end{tabular}

Dilihat dari hasil pengujian sebagaimana tercantum pada tabel menunjukkan hasil iklim organisasi dikategorikan kondusif, sedangkan kinerja pegawai dikategorikan tinggi di Bagian Sekretariat Dinas Pendidikan Provinsi Sumatera Barat.

Tabel 4. Korelasi Iklim Organisasi Kinerja Pegawai

\begin{tabular}{|l|l|l|r|}
\hline \multicolumn{2}{|c|}{ Corelation } \\
\hline \multicolumn{2}{|c|}{} & $\begin{array}{c}\text { Dukungan } \\
\text { Sosial } \\
\text { Orangtua }\end{array}$ & $\begin{array}{c}\text { Prokrastinasi } \\
\text { Akademik }\end{array}$ \\
\hline Iklim Organisasi & Person correlation & & 484 \\
& Sig. (2-tailed) & &, 001 \\
& N & 484 \\
\hline Kinerja Pegawai & Person correlation &, 001 & \\
& Sig. (2-tailed) & 44 & \\
& N & 484 \\
\hline
\end{tabular}

Berdasarkan Tabel.4 maka dapat diketahui bahwa pada nilai signifikansi menunjukkan angka 0,001 dan 0,001, berdasarkan data tersebut maka terdapat korelasi antara variable $\mathrm{X}$ dan variable $\mathrm{Y}$ di Bagian Sekretariat Disdik-Sumbar. Selanjutnya besarnya nilai koefisen korelasi antar variabel (X) dan variabel (Y) adalah 0,484. Dari hasil analisa data diketahui korelasi antar variabel berarah positif(+). 
Jadi berdasarkan hasil pengujian tersebut dapat ditarik kesimpulan adanya hubungnan antara variabel X dan variabel Y pada Bagian Sekretariat Disdik-Sumbar. Hal tersebut menunjukkan hipotesisi yang berbunyi "adanya hubungan antara iklim organisasi dengan kinerja pegawai" dapat diterima.

\subsection{Pembahasan}

\subsubsection{Kinerja Pegawai} kerjasama.

Aspek yang dilihat berdasarkan indikator kinerja pegawai yaitu kualitas, kuantitas dan

a. Kualitas

Berdasarkan hasil penelitian, item tertinggi pada indikator rata-rata 4,6 ialah item yang menyatakan bahwa pegawai menyelesaikan pekerjaan dengan baik. Hal ini berarti pegawai mengerjakan pekerjaan secara optimal dan sungguh-sungguh. Sedangkan untuk item yang mempunyai skor terendah pada indikator rata-rata 4,3 ini adalah terkadang kurang berkonsentrasi dalam menyelesaikan pekerjaan. Banyak hal yang dapat mengakibatkan pegawai kurang berkonsentrasi dalam pekerjaannya. Kurang berkonsentrasi bisa terjadi karena pegawai lelah saat mengerjakan tugas, keadaan tubuh yang kurang sehat pada saat bekerja, banyaknya masalah yang sedang dihadapi pegawai, adanya kegaduhan dalam ruangan kerja. Kurang konsentrasi menyebabkan pekerjaan yang diberikan tidak sesuai dengan yang diharapkan, walaupun pekerjaan selesai akan tetapi hasil yang didapatkan tidak memuaskan.

Beberapa faktor yang mengakibatkan pegawai kurang berknsenstrasi adalah lelah saat menyelesaikan pekerjaan, tubuh yang kurang sehat pada saat bekerja, banyaknya masalah yang sedang dihadapi pegawai, adanya kegaduhan dalam ruangan kerja. Upaya yang dapat dilakukan pimpinan adalah memperhatikan faktor-faktor yang mengakibatkan kurangnya konsentrasi, pimpinan memberikan perhatian kepada pegawai, melakukan pendekatan kepada pegawai yang dilihat kurang berkonsentrasi.

b. Kuantitas

Berdasarkan hasil penelitian, item tertinggi pada indikator rata-rata 4,45 ialah item yang menyatakan pegawai tidak merasa terbebani saat melaksanakan tugas. Dapat dilihat sebagian orang yang menyelesaikan pekerjaan tanpa harus dibantu oleh rekan kerja. Sedangkan untuk item skor terendah pada indikator ini yaitu pegawai merasa susah dalam berkerja, nilai rata - rata 3,64. Menunjukkan tingkat kekecewaan dalam bekerja masih tinggi.

Upaya yang bisa dilakukan untuk mengatasi kekecewaan dalam bekerja dengan cara berhenti mengeluh dan lakukan evaluasi diri sendiri, mencari hal positif, serta ingat kekecewaan dan kegagalan yang lampau.

c. Kerjasama

Berdasarkan hasil penelitian, item tertinggi pada indikator rata-rata 4,5 ialah item yang menyatakan pegawai mengerjakan tugas dengan tanggungjawab. Hal ini terlihat dari pegawai yang mengerahkan kemampuannya dalam menyelesaikan pekerjaan. Sedangkan untuk item skor terendah pada indikator ini yaitu pegawai kurang bisa membangun kerja sama tim dalam menyelesaikan pekerjaan dengan skor rata-rata 4,0. Hal ini berarti tingkat kerja sama tim dalam bekerja masih rendah.

Upaya yang bisa dilakukan untuk mengembalikan kerjasama tim hendaknya pegawai mau mengakui keterbatasan yang dimilkinya, selesaikan pertikaian dengan sling terbuka dan musyawarah

\subsubsection{Iklim Organisasi}

a. Kelengkapan Sarpras

Berdasarkan hasil penelitian penataan ruang kantor yang baik, peralatan kantor yang lengkap dan perabot kantor yang baik berada pada skor rata-rata indikator sebesar 4,4. Penataan ruang kantor yang baik, peralatan kantor yang lengkap dan perabot kantor yang baik menjelaskan bahwa pimpinan memperhatikan lingkungan kerja sehingga pegawai nyaman dalam menyelesaikan pekerjaan. Sedangkan item yang mempunyai skor terendah pada indikator ini disebabkan karena masih adanya pegawai yang mengalami kesulitan dalam menggunakan perlatan dan perabot kantor dengan skor rata-rata 4,3.

Upaya yang dapat dilakukan adalah pimpinan harus lebih memperhatikan kelancaran pegawai dalam menyelesaikan pekerjaan dan dapat membantu pegawai apabila terdapat 
kesulitan dalam menggunakan peralatan dan perabot kantor, pimpinan memperbarui peralatan dan perabot kantor, pimpinan menata kembali ruangan kantor untuk kenyamanan pegawai.

b. Kepercayaan

Hasil penelitian menunjukkan bahwa iklim organisasi pada Bagian Sekretariat Dinas Pendidikan Provinsi Sumatera Barat yang dilihat pada aspek kepercayaan sudah dengan skor rata-rata indikator tertinggi sebesar 4,6.

kepercayaan pegawai di Bagian Sekretariat Dinas Pendidikan Provinsi Sumatera Barat sudah di kategorikan tinggi, dampaknya dapat membuat suasana organisasi yang baik serta dapat mendukung tercapainya tujuan organisasi.

c. Dukungan Pimpinan

Berdasarkan penelitian, pimpinan memberikan kepercayaan kepada guru dalam pendelegasian tugas merupakan skor rata-rata indikator tertinggi yaitu 4,1. Hal ini berarti pimpinan memberikan tanggung jawab dan kepercayaan penuh kepada pegawai dalam pendelegasian tugas yang telah diberikan.

Adapun penghargaan yang dapat diberikan pimpinan dapat berbentuk intensif material dan non material. Insentif material dapat berupa uang dan barang. Sedangkan insentif non material pengukuhan, pemberian pujian, penempatan sesuai keahlian dan kesempatan promosi berdasaerkan prestasi, diatas prestasi standar.

d. Keterlibatan Pegawai

Berdasarkan penelitian, skor rata-rata tertinggi adalah 4,3 pada indikator ini yaitu pegawai menggunakan seragam yang telah ditentukan lembaga. Menurut Davis (1990:179) mengemukakan ada dua jenis keterlibatan, yaitu keterlibatan menatal dan emosional. Keterlibatan mental berkaitan dengan keterlibatan yang bersifat fisik dan keterlibatan emosional berkaitan dengan perasaan. Untuk itu pimpinan harus mengajak pegawai untuk selalu mengikuti dan mentaati peraturan lembaga yang telah ditetapkan. Upaya yang harus dilakukan pimpinan adalah pimpinan mengajak pegawai berpartisipasi dalam setiap acara yang diselenggarakan oleh lembaga.

\subsubsection{Hubunngan Antara Iklim Organisasi Dengan Kinerja Pegawai}

Merujuk pada perhitungan terhadap uji korelasi, diperoleh sebuah kesimpulan bahwa ada hubungan signifikan antara variabel X dan variabel Y pada Bagian Sekretariat Dinas Pendidikan Provinsi Sumatera Barat pada taraf kepercayaan $95 \%$.

Menurut Baedhowi dalam Hadiyanto (2004: 183) "iklim organisasi dipengaruhi oleh kebijakan dan praktek manajemen, struktur organisasi, teknologi dan lingkungan organisasi yang baik akan menghasilkan iklim yang baik berupa orientasi prestasi dan mengutamakan kepentingan pekerjaan sehingga menghasilkan kinerja yang baik dan kepuasan kerja".

Selain itu Handoko (2011: 194) menyatakan bahwa "berbagai kebijaksanaan dan kegiatan personalia mempunyai dampak pada iklim organisasi. Iklim organisasional ini memberikan suatu lingkungan kerja yang menyenangkan atau tidak menyenangkan bagi orang-orang dalam organisasi, dimana hal itu selanjutnya akan mempengaruhi kepuasan kerja karyawan".

Hasil penelitian memperlihatkan hubungan antara iklim organisasi dengan kinerja pegawai artinya semakin baik iklim organisasi maka kinerja pegawai juga semakin tinggi. Dari hasil tersebut Variabel X dan Varibel Y harus ditingkatkan secara bersamaan.

\section{Kesimpulan}

1. Iklim organisasi pada Bagian Sekretariat Disdik-Sumbar terletak di tingkat $82,07 \%$ dengan kategori kondusif.

2. Kinerja Pegawai pada Bagian Sekretariat Disdik-Sumbar berada pada tingkat pencapaian $86,53 \%$ dengan kategori tinggi.

3. Terdapat hubungan antara Variabel X dan Variabel Y pada Bagian Sekretariat Disdik-Sumbar baik pada taraf signifikansi 95\%. Hal ini disebabkan karena perolehan uji korelasi apabila nilai signifikansi $<0,05$ maka berkorelasi sedangkan jika nilai signifikansi $>0,05$ maka tidak berkorelasi. Nilai signifikansi menunjukkan angka 0,001 dan 0,001

\section{Daftar Rujukan}

Hadiyanto. 2004. Mencari Sosok Desentralisasi Manajemen Pendidikan Di Indonesia. Jakarta: PT Rineka Cipta.

Hadiyanto. 2016. Teori \& Pengembangan Iklim Kelas \& Iklim Sekolah. Jakarta: Kencana. 
Rindu Aria Friska ${ }^{1}$, Hadiyanto $^{2}$, Nurhizrah ${ }^{3}$, Hanif Al Kadri ${ }^{4}$ Hubungan Iklim Organisasi dengan Kinerja Pegawai di Bagian Sekretariat Dinas Pendidikan Provinsi Sumatera

Handoko, T. Hani. 2011. Manajemen Personalia Dan Sumber Daya Manusia. Yogyakarta: BPFE.

Mutaqin, W. R. 2010. "Pengaruh Iklim Organisasi, Etos Kerja Dan Disiplin Kerja Terhadap Efektifitas Kinerja Organisasi Di Politeknik Kesehatan Surakarta.” Universitas Sebelas Maret.

Sugiyono. 2009. Metode Penelitian Kuantitatif Dan Kualitatif Dan R \& D. Bandung: Alfabeta. 